\title{
Some characteristics of the seismicity of the Tyrrhenian Sea Region
}

\author{
S. Mészáros - P. Hedervári (*)
}

Received on July 1st, 1974

Summare. - In the first part of the paper the seismic strain release of the Tyrrhenian Sea Region (including Italy), as the function of time, is examined on the basis of the data of the earthquakes that took place from 1901.01 .01 to 1970.12 .31 , between the northern latitudes of $34^{\circ}$ and $44^{\circ}$ and between the eastern longitudes of $8^{\circ}$ and $18.5^{\circ}$, respectively. All registered shocks with a Richter-magnitude of 5.5 or over it were considered, independently from the focal depth. Three periods were recognized in the activity; the lengths of which are not the same, however.

In the second part the elastic strain release in accordance with the focal depth of the same earthquakes is treated briefly. It was found that the total strain-release had a maximum value in the depth between 0 and $74 \mathrm{kms}$ and there was a minimum between the depth of 300 and $524 \mathrm{kms}$ with an interval between 375 and $449 \mathrm{kms}$ within which no earthquakes occurred at all. The general pattern of the distribution of seismicity as the function of hypocentral depth reminds to the well-known picture, one can experience in other regions where intermediate and deep shocks occur. This statement is consistent with the idea, according to which the seismicity of the Tyrrhenian Sea Region can be discussed and explained in the light of the theory of new global tectonies.

Finally, in the third part of the study, the authors have stated that in some cases multiple events oceurred beneath the Tyrrhenian Sea Region. Such multiple seisnic events were detected in the ease of other areas, such as the Fiji-Tonga-Kermadec Region, the seismic belt of South Anerica ete., - but, according to the linowledge of the authors, this is the first occasion when multiple seismic events are demonstrated in the Tyrrhenian Sea Regrion.

(*) Hungarian Research Group on Geophysical Volcanology; 11. 1023, Budapest, II. Arpad fejedelem utja 40-41, IV/3, Hungary. Contribution No. OT/7H/LRGGT. 
Rrassusto. - Nella prima parte della nota viene studiata l'energia sismica liberata nella regione del Mar 'Tirreno (Italia compresa) in funzione del tempo, in hase ai dati di terremoti che ebbero luogo, dal 1-I-1901 al 31-XII-1970, fra i $34^{\circ}$ e i $44^{\circ}$ di latitudine Nord e gli $8^{\circ}$ e i $18^{\circ}, 5$ di longitudine Est, rispettivamente. Sono state prese in esame tutte le scosse registrate con magnitudo $\geqslant 5,5$ (magn. Richter), indipendentemente dalla profondita ipocentrale. I periodi di attivita studiati sono stati tre, la cui durata tuttavia non è stata sempre la stessa.

Nella seconda parte, vengono brevemente trattate le tensioni elastiche liberate in relazione alla profondità ipocentrale, sempre dagli stessi terremoti. Si è trovato che la tensione totale liberata ha il massimo valore alla profondità compresa fra 0 e $74 \mathrm{~km}$, il minimo fra i 300 e i $524 \mathrm{~km}$, mentre nell'intervallo fra i 375 e i $441 \mathrm{~km}$ non si è avuto alcun terremoto. Il modello generale della distribuzione di sismicita in funzione della profondità ricorda quello ben noto, relativo a scosse che avvengono a profondita intermedia e profonda. Questa asserzione è compatibile con l'idea secondo cui la sismicità della regione del Mar Tirreno può essere discussa e spiegata alla luee della teoria di nuove tettoniche globali.

Infine, nella terza parte della nota, gli A.A. hamno trovato che in aleuni casi, eventi molteplici sono avvenuti al di sotto della rerione del Mar Tirreno. Eventi simili si sono manifestati anche in altre zone, come quelle delle Isole Fiji, Tonga e Kermadec, l'areo sismico del Sud America etc., ma a conoscenza degli A $A$., è questa la prima volta che viene dimostrato che eventi sismici molteplici avvengono nella regione del Mar Tirreno.

\section{1. - Temporal Variation of Elastic Strain Release}

As a "by-product" of another investigation, belonging to the program of the Hungarian Research Group on Geophysical Folcanology, we have compiled a list of the earthquakes of the Tyrrhenian Sea Region (Table I), and on this basis we made some investigations as regards the seismicity of our area. At first we constructed a graph to show the elastic strain release characteristics of the region uncler consideration. The data of earthquakes No. 1. To. 40 originally were given by Karník $\left({ }^{\circ}\right)$. The data of the shocks No. 41. $\mapsto$ No. 66 were published by Rothe ( $\left.{ }^{8}\right)$. Rothe's referrerl book consists of all the registered earthquakes that occurred until the end of 1965 . Data of shocks, took place between 1966.01.01 and 1970.12.31 are to be found in the volumes of Regional Catalogue of Earthquakes, issued by the International Scismological Centre, Edinburgh.

We wish to point out that we took into consideration all earthquakes of tectonic origin, provided that their Richter-magnitude 
TABJE I

\begin{tabular}{|c|c|c|c|c|c|c|}
\hline No. & Wate & Iuat. & Long. & $\stackrel{h}{h}$ & W & $\sum_{\operatorname{ergs}^{0} s^{0.5} \cdot 10^{10}} \mathbb{1}^{0.5}$ \\
\hline 1 & 1901.07 .22 & 43.0 & 17.6 & n & 5.7 & 1.50 \\
\hline 2 & 1901.08 .10 & 44.0 & 15.6 & $\mathrm{n}$ & 5.7 & 3.00 \\
\hline 3 & 1902.04 .26 & 44.0 & 16.2 & $n$ & 5.7 & 4.50 \\
\hline 4 & 1904.02 .24 & 42.1 & 13.2 & n & 5.6 & 5.76 \\
\hline 5 & 1905.09 .08 & 38.8 & 16.1 & n & 7.3 & 29.48 \\
\hline 6 & 1907.08 .01 & 43.2 & 17.6 & n & 5.7 & 30.98 \\
\hline 7 & 1907.10 .23 & 38.0 & 16.1 & n & 5.9 & 33.09 \\
\hline 8 & $1908.12 .28 *$ & 38.0 & 15.5 & 10 & 7.0 & 47.25 \\
\hline 9 & 1910.06 .07 & 40.9 & 15.4 & $\mathrm{n}$ & 5.9 & 49.36 \\
\hline 10 & 1910.08 .01 & 39.0 & 15.0 & $200 \pm$ & 6.8 & 59.36 \\
\hline 11 & 1911.04 .05 & 40.0 & 15.5 & $200 \pm$ & 6.3 & 63.58 \\
\hline 12 & 1913.06 .28 & 39.5 & I 6.3 & $n$ & 5.5 & 64.64 \\
\hline 13 & 1915.01 .13 & 42.0 & 13.5 & 10 & 6.8 & 74.64 \\
\hline 14 & 1915.07 .07 & 39.0 & 15.0 & 275 & 5.9 & 76.75 \\
\hline 15 & 1917.04 .26 & +3.5 & 12.1 & $\mathrm{n}$ & 5.5 & 77.81 \\
\hline 16 & 1918.11 .10 & +3.8 & 11.9 & $n$ & 5.7 & 79.31 \\
\hline 17 & 1919.06 .29 & $4+.0$ & 11.5 & $n$ & 6.2 & 82.86 \\
\hline 18 & 1919.10 .22 & 41.4 & 12.6 & $\mathrm{n}$ & 5.6 & 84.12 \\
\hline 19 & 1922.12 .29 & 41.8 & 13.7 & n & 5.5 & 85.18 \\
\hline 20 & 1923.02 .06 & 43.3 & 17.2 & $n$ & 5.5 & 86.24 \\
\hline 21 & 1923.03 .15 & 43.3 & 17.1 & n & 6.2 & 89.79 \\
\hline 22 & 1923.09 .18 & 35.5 & 14.5 & $\mathrm{n}$ & 5.5 & 90.85 \\
\hline 23 & 1926.08 .17 & 39.0 & 14.7 & 100 & 6.0 & 93.36 \\
\hline 24 & 1928.03 .07 & 38.5 & 16.0 & 100 & 6.6 & 100.44 \\
\hline 25 & 1930.07 .23 & 41.1 & 15.4 & 7 & 6.5 & 106.40 \\
\hline 26 & 1930.10 .30 & 43.7 & 13.3 & 4 & 5.9 & 108.51 \\
\hline 27 & 1933.09 .26 & 42.0 & 14.2 & 10 & 5.5 & 109.57 \\
\hline 28 & 1937.10 .17 & 39.3 & 15.2 & 300 & 5.8 & 111.35 \\
\hline 29 & 1938.04 .13 & 39.3 & 15.2 & 275 & 7.1 & 128.15 \\
\hline 30 & 1939.05 .27 & 42.0 & 17.3 & $\mathrm{n}$ & 5.5 & 129.21 \\
\hline 31 & $19+1.03 .16$ & 38.3 & 12.2 & 100 & 6.9 & 141.09 \\
\hline 32 & $19+1.03 .16$ & 38.3 & 12.2 & $100 ?$ & 6.2 & 144.64 \\
\hline 33 & $19+2.12 .29$ & 43.4 & 17.2 & $\mathrm{n}$ & 6.0 & 147.15 \\
\hline 34 & 1943.09 .17 & 39.5 & 15.2 & $270 \pm$ & 5.5 & 148.21 \\
\hline 35 & 1947.05 .11 & 38.7 & 16.8 & 30 & 5.6 & 149.47 \\
\hline 36 & $19+7.07 .31$ & 39.2 & 15.2 & $290 \pm$ & 5.6 & 150.73 \\
\hline 37 & 1950.09 .05 & 42.5 & 13.3 & $\sim 35$ & 5.5 & 151.79 \\
\hline 38 & 1952.12 .26 & 39.8 & 15.6 & 265 & 6.2 & 155.34 \\
\hline 39 & 1954.11 .23 & 38.5 & 14.9 & 230 & 5.8 & 157.12 \\
\hline
\end{tabular}

(*) The Messina earthquake 
Segue table I

\begin{tabular}{|c|c|c|c|c|c|c|}
\hline No. & Datr & $\begin{array}{l}\text { Iat. } \\
\text { oN }\end{array}$ & Long. & $\underset{\lim }{h}$ & $M$ & $\sum_{\operatorname{ergs}^{0,5} \cdot 10^{10}} \mathbf{E}^{0,5}$ \\
\hline 40 & $1955.02 .17 *$ & 39.6 & 13.1 & 450 & 5.6 & 158.38 \\
\hline 41 & 1956.02 .01 & 39.1 & 15.6 & 215 & 6.4 & 163.40 \\
\hline 42 & 1956.08 .15 & 43.2 & 16.0 & $\mathbf{n}$ & 6.0 & 165.91 \\
\hline 43 & 1957.02 .20 & 36.2 & 8.9 & $\mathrm{n}$ & 5.6 & 167.17 \\
\hline 44 & 1957.05 .20 & 38.7 & 14.1 & 60 & 5.8 & 168.95 \\
\hline 45 & 1957.05 .21 & 38.7 & 14.1 & $\mathrm{n}$ & 6.1 & 171.94 \\
\hline 46 & 1958.06 .24 & 42.2 & 13.4 & $\mathrm{n}$ & 5.5 & 173.00 \\
\hline 47 & 1959.12 .23 & 37.7 & 14.4 & 100 & $\tilde{5.5}$ & 174.06 \\
\hline 48 & 1960.01 .03 & 39.5 & 15.5 & 250 & 6.2 & 177.61 \\
\hline 49 & 1961.03 .23 & 43.6 & 12.6 & 25 & 5.5 & 178.67 \\
\hline 50 & 1961.05 .10 & 35.1 & 15.8 & $\mathrm{n}$ & 5.5 & 179.73 \\
\hline 51 & 1961.12 .02 & 36.9 & 8.0 & n & 5.5 & 180.79 \\
\hline 52 & 1962.01 .07 & 43.2 & 17.1 & $\mathrm{n}$ & 6.0 & 183.30 \\
\hline 53 & 1962.01 .11 & 43.3 & 17.0 & n & 6.1 & 186.29 \\
\hline 54 & 1962.03 .25 & 39.1 & 14.7 & 343 & $\tilde{5.5}$ & 187.35 \\
\hline 55 & 1962.04 .17 & 42.4 & 17.4 & 25 & 5.5 & 188.41 \\
\hline 56 & 1962.06 .11 & 43.6 & 18.3 & $\mathrm{n}$ & 6.3 & 192.63 \\
\hline 57 & 1962.08 .21 & 41.1 & 15.1 & 36 & 5.6 & 193.89 \\
\hline 58 & 1962.08 .21 & 41.1 & 15.1 & 34 & 6.1 & 196.88 \\
\hline 59 & 1962.08 .21 & 41.2 & 15.1 & n & 6.0 & 199.39 \\
\hline 60 & 1963.02 .13 & 40.7 & 15.6 & n & 5.5 & 200.45 \\
\hline 61 & 1963.02 .17 & 43.9 & 17.2 & n & 5.5 & 201.51 \\
\hline 62 & 1963.06 .01 & 39.0 & 15.0 & 285 & 5.5 & 202.57 \\
\hline 63 & 1963.07 .19 & 43.4 & 8.2 & n & 5.7 & 204.07 \\
\hline 64 & 1963.07 .19 & 43.4 & 8.2 & $\mathrm{n}$ & 6.2 & 207.62 \\
\hline 65 & 1963.09 .29 & 36.1 & 18.0 & 47 & 5.7 & 209.12 \\
\hline 66 & 1964.04 .14 & 39.0 & 14.5 & 306 & $\tilde{\mathbf{5}} . \tilde{5}$ & 210.18 \\
\hline
\end{tabular}

(*) The deepest shock ever observed in the Tyrrhenian Sea Region

reached the value of 5.5 . It is noteworthy, furthermore, that on our area investigated no earthquakes of $M \geq 5.5$ occurred between 1966.01.01 and 1970.12.31. Magnitude $d$, can be found in certain cases in the catalogues, was regarded by us as $M=5.5$.

For the calculation of seismic energy we have employed the wellknown equation, due to Gutenberg and Richter:

$$
\log E=11.8+1.5 M,
$$

where $E$ is the relensed seismic energy, expressed in ergs and $M$ the 
Richter-magnitude. The elastic strain release is proportional to $E^{0,5}$ and its dimension is ergso,s.

Our Fig. 1, shows the characteristics of the distribution of elastic strain release as the function of time. On the diagram altogether three periorls of activity can be recognized, although the beginning of the first one is not known. The first periorl, namely, began before 1901 .

It seems that the first period ender (and the second one began) in the year 1926 . The end of the second period and the beginning of the third one can be found in 1941. It can be supposed, furthermore, than the third period ended in 1964 and since this time at least until the end of 1970 ) there was a calm period, which may be the introducing part of a longer periorl of activity.

In Table I $h$ means the focal dopth and $N$ means a "normal" depth, for which $0<h \leqslant 70 \mathrm{~km}$.

$$
\sum E=\sum_{x .1}^{x_{0.0} 66} E=1741.571 \cdot 10^{20} \mathrm{ergs.}
$$

Thus the total energy corresponds to an individual earthoualie the magnitude of which amounts roughly to 7.63 .

The average energy can be computed by using the formula:

$$
\bar{E}=\frac{\sum E}{n}
$$

where $n$ is the number of shocks considered, that is $n=66$. The result is:

$$
\bar{E}=26.387 \cdot 10^{20} \mathrm{ergs}
$$

The equivalent magniturle of this energy is $\mathbf{6 . 4 1}$.

This value permits us to take an interesting comparison with other areas. According to an earlier sturly of one of us ("), the so called equivalent magnitude of the "North Polar Region" [Area $41\left({ }^{3}\right)$ ], furthermore that of the "Pacific Basin" [Area $39\left(^{3}\right)$ ], "Tasmania to Antarctica and Antarctica" [Areas 45 and $50\left(^{3}\right)$ ], and "Fiji Island" [Area $13\left({ }^{3}\right)$ ] is between 6.00 and 6.49 ; although in the quoted paper for the calculation of the equivalent magnitude the equation

$$
M_{\text {equ }}=\left\lfloor\log \left(\frac{\sum_{t_{1}}^{t_{2}} E}{k}\right)-11.0\right\rfloor \cdot 1.6^{-1}
$$




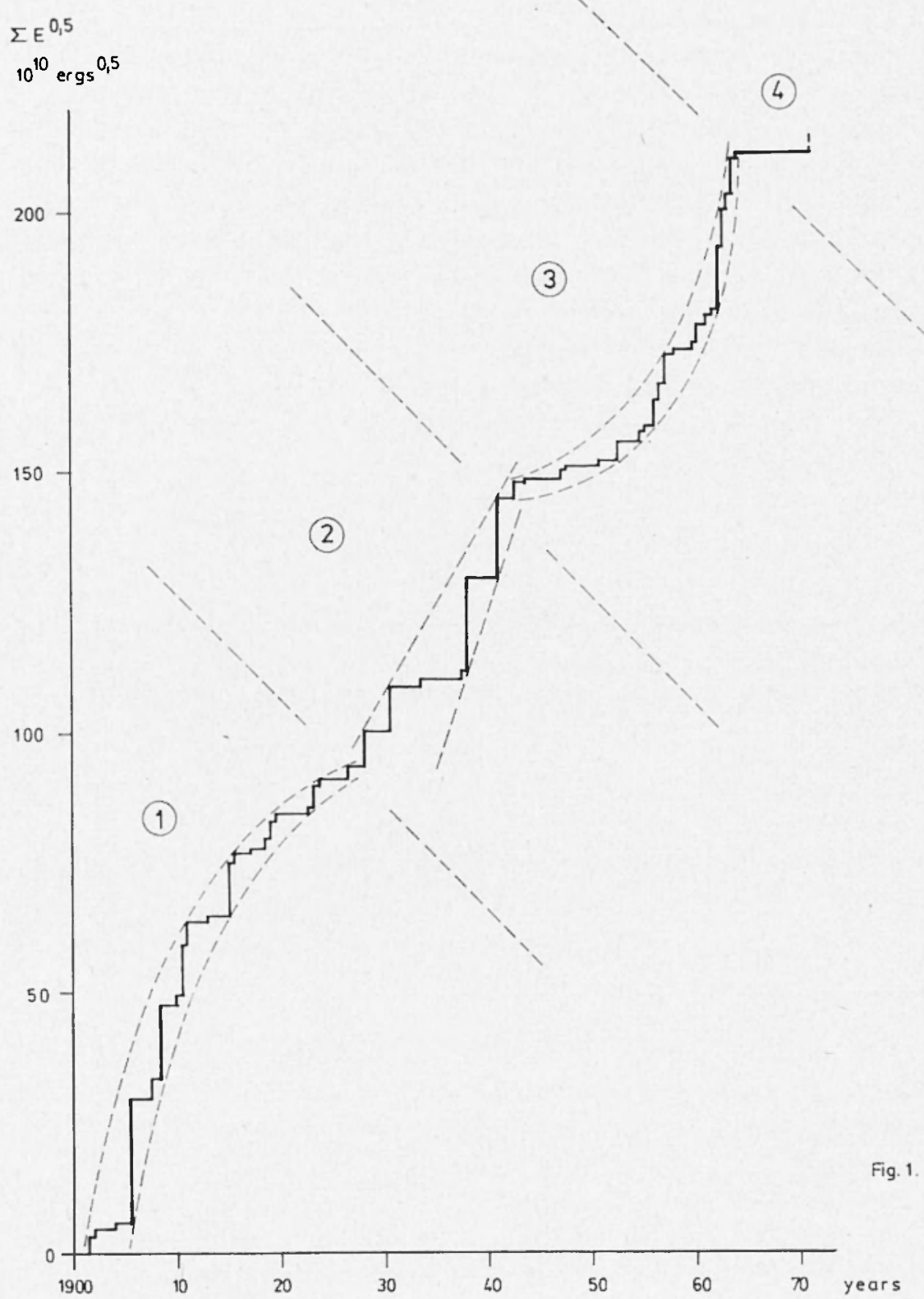

Fig. I - Cumulative curve of the value $\sum E^{0.5}$ for the Tyrrhenian Sea Region. 1, 2, 3 and 4 mean periods of activity; the beginning part of period 1 as well as the continuation of period 4 is unknown as yet. For all the observed shocks, independently from the focal depth, $M \geqslant 5.5$. 
was employed, instead of the expression

$$
M_{\text {equ }}=\left[\log \left(\frac{\sum_{t_{1}}^{t_{2}} E}{k}\right)-11.8\right] \cdot 1.5^{-1} .
$$

In [1] and [2] $k$ is the number of all earthquakes, occurred within the time-interval $t_{1} \mapsto t_{2}$ over the area examined, $E$ the released seismic energy and $M_{\text {equ }}$ the equivalent magniturle. Equation [2] corresponds to the expression

$$
\log E=11.8+1.5 M
$$

which today is generally accepted, but when the above-mentioned investigation had been in preparation, we employed the earlier formula, according to which

$$
\log E=11.0+1.6 M .
$$

Taking into account the fact that for the Tyrrhenian Sea Region

$$
M_{\text {equ }}=6.41,
$$

we can state that on a world scale the seismicity of the Tyrrhenian Sea Region is rather slight, in spite of the fact that a few earthquakes had a magnitude of 7.0 or greater. By other worls the seismic level of our region investigated is comparable with that of Areas 44, 39, 45,50 and 13 of Gutenberg and Richter $\left({ }^{3}\right)$.

Using equation [1] we have classified the surface of the Earth

\begin{tabular}{|c|c|}
\hline$M_{\text {equ }}$ & Category \\
\hline $\begin{array}{l}0.00-5.99 \\
6.00-6.49 \\
6.50-6.99 \\
7.00-7.49 \\
7.50-8.00\end{array}$ & $\begin{array}{l}\text { I } \ldots \ldots \text { Aseismic and very weakly seismic } \\
\text { II } \ldots \ldots \text { Weakly seismic } \\
\text { II } \ldots \text {. Moderately seismic } \\
\text { IV } \ldots \text {. Strongly seismic } \\
\text { V..... Very strongly seismic }\end{array}$ \\
\hline
\end{tabular}
in accordance with the value of the equivalent magnitude. This is given in Table $\mathbf{I I}$.

TABLE II 
The Areas, mentioned above, fall into Category II, and the same is true for the case of the Tyrrhenian Sea Region as well.

\section{2. - Spatial Variatiox of Elaste Strias Reisase}

In this chapter the clistribution of seismic activity accorling to the focal depth will be examiner on the basis of rata, presenter in Table I. At first we show the effective rata:

TABLE III

\begin{tabular}{|c|c|c|}
\hline $\begin{array}{c}\text { Foeal rlepth } \\
h \\
\mathrm{~km}\end{array}$ & $\sum E^{0.5}, \operatorname{ergs}^{0.5} \cdot 10^{10}$ & $\begin{array}{l}\text { Number of } \\
\text { shocks }\end{array}$ \\
\hline \multirow[t]{2}{*}{$0 \ldots 70$} & & \\
\hline & 128.53 & 46 \\
\hline 100 & 26.08 & 5 \\
\hline 200 & 14.22 & 2 \\
\hline 215 & 5.02 & 1 \\
\hline 230 & 1.78 & 1 \\
\hline 250 & 3.55 & 1 \\
\hline 265 & 3.55 & 1 \\
\hline 270 & 1.06 & 1 \\
\hline 275 & 18.91 & 2 \\
\hline 285 & 1.06 & 1 \\
\hline 290 & 1.26 & 1 \\
\hline 300 & 1.78 & 1 \\
\hline 306 & 1.06 & 1 \\
\hline 343 & 1.06 & 1 \\
\hline \multirow[t]{2}{*}{450} & 1.26 & 1 \\
\hline & 210.18 & 66 \\
\hline
\end{tabular}


Inividing the Earth's interior into horizontally lying layers, the thickness of which is $7.1 \mathrm{kms}$, we received the following values:

TABIE IV

\begin{tabular}{|c|c|}
\hline $\begin{array}{c}\text { Layer } \\
\text { km }\end{array}$ & $\sum E^{0.5}, \operatorname{crgs}^{0.5} \cdot 10^{10}$ \\
$0-74$ & 128.53 \\
$75-149$ & 26.08 \\
$150-224$ & 19.24 \\
$225-299$ & 31.17 \\
$300-374$ & 3.90 \\
$375-449$ & 0 \\
$450-524$ & 1.26 \\
\hline
\end{tabular}

The general pattern of the distribution of seismic activity with the depth beneath the Tyrrhenian Sea Region is very similar to those ones, which are experienced in other areas, where intermediate as well as deep earthquakes take place. For example, let us see the curve, representing the variation of elastic strain release in the case of the Sunda Are (7); or the diagrams, valid for the Earth as a whole (1,2) and let us compare these curves (Fig. 2) with the one, valid for the Tyrrhenian Sea Region (Fig. 3). The two most conspicnous features of these curves are as follows:

a) - A strong maximum is existing in the uppermost layer, that is near the Earth's surface;

b) - One can find a remarkable minimum around the depth of $420-.450 \mathrm{kms}$.

It is well-known by way of many other research that the theory of global plate tectonics is excellently applicable for the case of the Tyrrhenian Sea Region as well. The pattern of the variation of seismic activity with the depth in the case of our area investigated is perfectly consistent with the models of plate tectonics. 


$$
\begin{aligned}
& \sum E^{0,5} \\
& \operatorname{ergs} 0,5
\end{aligned}
$$
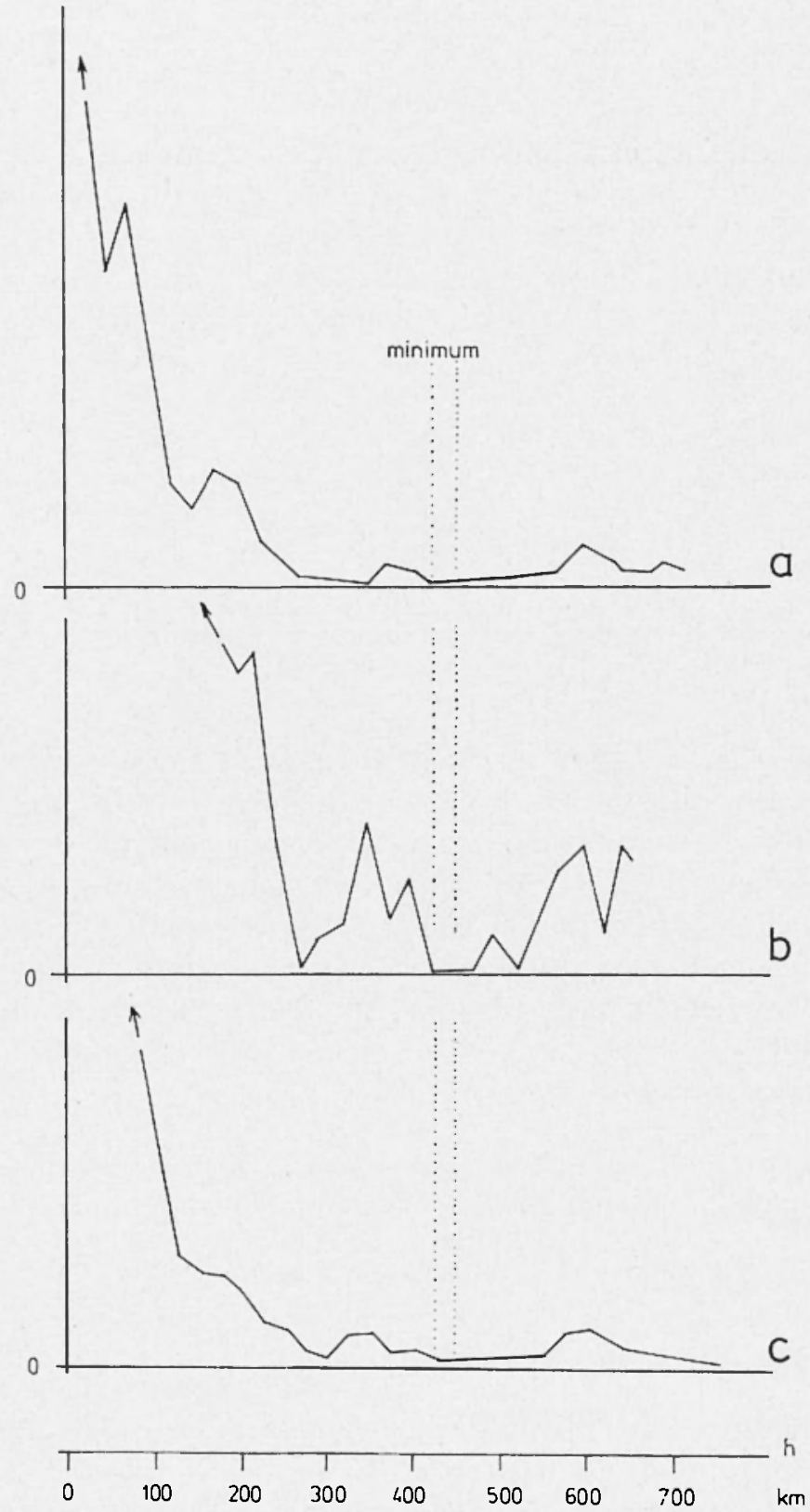

Fig. 2 - Seismic activity versus focal depth. a) For the Sunda arc [after Ritsema ()]; b) for the liarth as a whole [from the data of Bath and J)uda (1)]; c) for the Earth as a whole [from the data of Galanopoulos $\left({ }^{2}\right)$ ]. 


\section{3. - Multipie Seisuitc Events}

Isacks, Sykes and Oliver $\left(^{5}\right)$ have demonstrated that certain earthquakes exhibit "clustering" which refers to a concentration of shocks both in space and time. The earthquake-sequences and swarms can be regarded as special kinds of elusters. The earthqualie-sequences of shallow events are usually called aftershocks, provided that at the beginning of the series there is a strong shock with a higher magnitude, called main-shock. In the absence of a main-shock we often speak
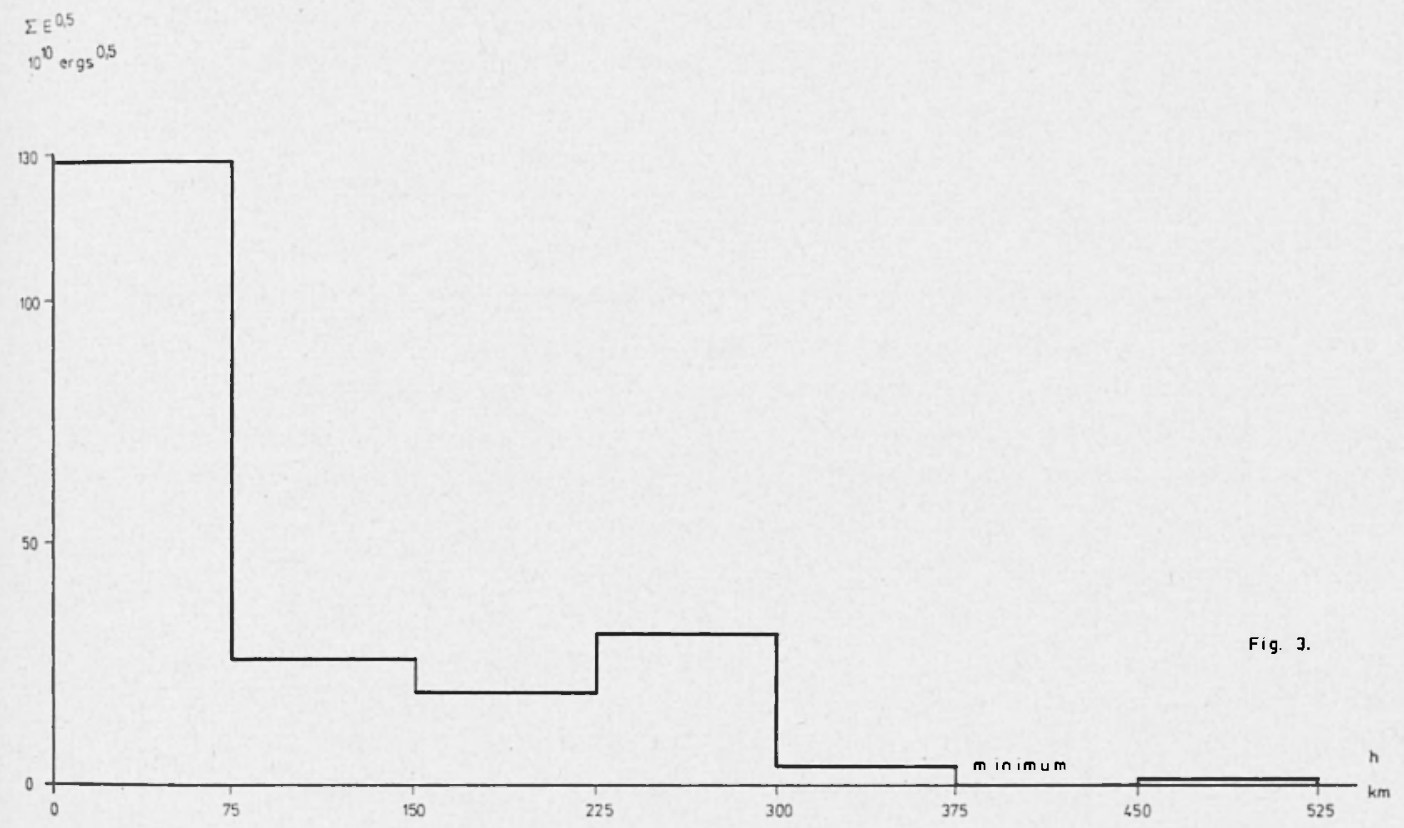

Fig. 3 - Seisnic activity versus focal depth in the case of the Tyrrhenian Sea Region (for a detailed explanation see the text).

about swarms, the members of which are more or less similar to one another in their magnitudes. Swarms usually are of volcanic origin while the sequences are due to tectonic causes. The aftershock-sequences as well as the swarms include large number of events. Intermediate and deep earthquakes, however, do not exhibit such sequences and swarms. Many intermediate and deep shocks are alone, that is without well-observable connection with other intermediate and deep events; 
but some of them occur in clusters. The hypocenters of the members of such clusters are very near to one another in the space; sometimes the foci are the same or are only in a clistance $1-2$ to 80 kilometres from one another. The time-interval between the occurrence of the events may be as low as some seconds (!) (5) or some hours or about one day $\left({ }^{9}\right)$. In the Fiji-Tonga - Kermadec Region most deep multiplets were doublets, some were triplets and there were cases when 7.8 or even 12 events follower fastly, one after the other, from foci which were very near to one another. Clustering of earthquakes were observer beneath the North Island (New Zealand), at the Bonin Islands Region, at the Solomon Islands and in the seismic belt of South America, too. Now we shall show that some clusterings occurrer in the case of the Tyrrhenian Sea Region as well. The clusters are listed in Table $\mathrm{V}$.

\section{TABLE V}

\begin{tabular}{|c|c|c|c|c|c|c|c|c|}
\hline No. & Date & $\mathrm{h}$ & $\mathrm{m}$ & $\mathbf{s}$ & $\begin{array}{l}\text { Lat. } \\
\text { oN }\end{array}$ & Long. & $\begin{array}{c}h \\
\mathrm{~km}\end{array}$ & $M$ \\
\hline 31 & 1941.03 .16 & 16 & 35 & 02 & 38.3 & 12.2 & 100 & 6.9 \\
\hline 32 & 1941.03 .16 & 18 & 48 & 21 & 38.3 & 12.2 & $100 ?$ & 6.2 \\
\hline 44 & 1957.05 .20 & 19 & 57 & 34 & 38.7 & 14.1 & 60 & 5.8 \\
\hline 45 & 1957.05 .21 & 11 & 44 & 06 & 38.7 & 14.1 & n & 6.1 \\
\hline 57 & 1962.08 .21 & 18 & 09 & 07 & 41.1 & 15.1 & 36 & 5.6 \\
\hline 58 & 1962.08 .21 & 18 & 19 & 33 & 41.1 & 15.1 & 34 & 6.1 \\
\hline 59 & 1962.08 .21 & 18 & 44 & 51 & 41.2 & 15.1 & $\mathrm{n}$ & 6.0 \\
\hline 63 & 1963.07 .19 & 05 & 45 & 28 & 43.4 & 8.2 & n & 5.7 \\
\hline 64 & 1963.07 .19 & 05 & 46 & 05 & 43.4 & 8.2 & $\mathrm{n}$ & 6.2 \\
\hline
\end{tabular}

We should like to point out that there were two interesting cases for which the foci seems to be very near to one another, the timedifference between the occurrence of the events, however, was greater 
than one day. We call such events as quasi-multiplets. The data of these quasi-multiplets are to be found in Table VI.

TABIE VI

\begin{tabular}{|c|c|c|c|c|c|c|c|c|}
\hline No. & Date & $\mathrm{l}$ & $m$ & $\mathrm{~s}$ & $\begin{array}{l}\text { Lat. } \\
\text { oN }\end{array}$ & I Long. & $h$ & $M$ \\
\hline 52 & 1962.01.07 & 10 & 03 & 14 & 43.2 & $1 \bar{i} .1$ & n & 6.0 \\
\hline 53 & 1962.01 .11 & 05 & 05 & 04 & 43.3 & 17.0 & $\mathrm{n}$ & 6.1 \\
\hline $\begin{array}{l}63 \\
64 \\
64:\end{array}$ & $\begin{array}{c}\text { See in Table } V \\
\text { See in Table } V \\
1963.07 .27\end{array}$ & 05 & 58 & 23 & 43.5 & 8.4 & $\mathrm{n}$ & 5.4 \\
\hline
\end{tabular}

It is interesting to note that in the case of all shallow multiplets as well as in the case of one of the quasi-multiplets the magniturle of the first shock is smaller than that of the second quake, contrary to the case of normal shallow earthquake-sequences, where usually the first shock is the strongest within the whole series and the so called foreshocks are rather rare phenomena.

\section{4. - Coxchusions}

The main theses of this article can be summarized as follows:

a) Although the seismicity of the Tyrrhenian Sea Region is remarkable relative to other parts of Europe and many of the marginal seas of this continent, it is relatively slight on a world scale. The temporal variation of elastic strain release is not a regular process: on the contrary, at least three periorls of diflerent lengths can be distinguished between 1901 and 1971 .

b) The pattern of the spatial variation of elastic strain release - that is the pattern of seismic activity in accordance with the hypocentral depth — is similar to the cases, one can experience beneath other areas, where intermerliate $(h=70 \curvearrowleft 300 \mathrm{~km})$ and doep 
(h $>300 \mathrm{~km})$ shocks occur. The deepest shock, ever observed on our region under investigation originater in a depth of about $450 \mathrm{~km}$ beneath the surface.

c) The new theory of global plate tectonics is applicable for the case of the Tyrrhenian Sea Region. In another paper we showed that a part of the $\Lambda$ frican lithosphere is being consummater underneath the Tyrrhenian Sea and the dip-angle of the Benioff-zone, developer there, is about $51-52$ degrees. "Seeing from volcano Stromboli the greatest dip - as it is revealed by the inclined seismic zone, by other words: by the Benioff-zone - can be experienced in the direction of $\mathrm{N} 64^{\circ} \mathrm{W}$ approximately" (from the Abstract of the paper: "Some Words on the Deep Structure of Italian Toleanoes", "Contribution No. 06/74/HRGGV).

d) In the occurrence of both shallow and intermediate earthquakes, we can observe certain clustering, more or less similar to the case of the Fiji-Tonga-Kermadec Region as well as some other parts of the world.

\section{REFERENCES}

(1) BATII, MI., DUDA, S. J., 1963. - Strain Release in Relation to Focal Depth. "Geofisica Pura e Applicata", 56, pp. 93-100.

(2) Gatayopoulos, A. G., 1964. - Note on Strain Release Variation with Depth. "Annali di Geofisica", XVII.

(3) Gutenderg, B., Ricimen, C. F., 1954. - Seismicily of the Earth. Princeton.

(4) IÍ́denvíri, P., 1964. - Investigations Regarding the Earth's Seismicity. Part II: The Circumpacifical, Indonesian and Eurasian Earlhquake Bells. "Gerlands Beiträge zur' Geophysik", 73, 4.

(5) Is Acks, B. I., Sykes, I. R. and OLIver, J., 1967. - Spatial and Temporal Clustering of Deep and Shallow Earthquales in the Fiji-Tonga-Kermadec Region. "Bull. Seis. Soc. of $\Lambda \mathrm{m}$.", 57, 5 .

(") Kúní, V., 1968. - Seismicity of the European. Area. 1, Praha.

(7) Ritsema, A. R., 1954. - The Seismicity of the Sumda Are in Space and Time. "Inrlonesian Journal for Natural Scienee", Nos. 1, 2, 3.

$\left.{ }^{8}\right)$ Rotie, J. P., 1969. - The Seismicity of the Earth 1953-1965. Paris.

$\left({ }^{9}\right)$ Saxto, T., 1969. - Characteristics of Seismicily in South America. "Bull. Earth. Res. Inst.", 47, 4. 